\title{
SOME PROBLEMS OF APPLICATION BY ARBITRATION COURT OF SIMPLIFIED PROCEDURES IN A BANKRUPTCY CASE
}

\author{
Svetlana P. Kovalenko \\ Kuban State University, Krasnodar, Russian Federation
}

\begin{abstract}
Introduction: the paper investigates the existing problems of the simplified procedure of bankruptcy of absentee debtors and those in liquidation. The parties of the simplified bankruptcy procedure are analyzed, as well as the consequences of the exclusion of persons participating in corporate relations from the USRLE are revealed. The purpose of the study is to systematically analyze the problems of the current legislation on bankruptcy in the framework of a simplified bankruptcy procedure. Methods: the methodology of this article is based on the general scientific approach of positivist materialism. The general scientific methods of cognition are applied: analysis, synthesis, the hypothetical-deductive method, induction; as well as specific scientific methods: legal-dogmatic, systemic, structural-functional. Results: it is proved that at present the legislation is not sufficiently regulated: legal acts do not take into account all the specifics and features of the simplified bankruptcy procedure. The existing methods of solving the problems provided by the law are not always effective; a particular difficulty arises when the debtor is a participant of corporate legal relations. Based on the experience of the arbitration law enforcement, it is proved that the persons controlling the debtor have the possibility of abuse of their right. Conclusions: the legal institution under consideration needs to be permanently improved taking into account the emerging uniformity of the judicial application of the bankruptcy rules. In the absence of institutional innovations in the field of bankruptcy in Russia it is impossible to create a competitive market environment, and moreover, it is impossible to improve the investment climate.
\end{abstract}

Key words: bankruptcy, simplified procedure, creditor, debtor, corporation, corporate legal relations.

Citation. Kovalenko S.P. Some Problems of Application by Arbitration Court of Simplified Procedures in a Bankruptcy Case. Legal Concept, 2019, vol. 18, no. 3, pp. 116-120. (in Russian). DOI: https://doi.org/10.15688/ lc.jvolsu.2019.3.17

УДК 347

ББК 67.410 .1
Дата поступления статьи: 17.05.2019

Дата принятия статьи: 05.06.2019

\footnotetext{
НЕКОТОРЫЕ ПРОБЛЕМЫ ПРИМЕНЕНИЯ АРБИТРАЖНЫМ СУДОМ УПРОЩЕННЫХ ПРОЦЕДУР В ДЕЛЕ О БАНКРОТСТВЕ

\author{
Светлана Павловна Коваленко
}

Кубанский государственный университет, г. Краснодар, Российская Федерация

Введение: в статье исследуются существующие проблемы упрощенной процедуры банкротства отсутствующих и ликвидируемых должников. Проанализирован субъектный состав упрощенной процедуры банкротства, а также выявлены последствия исключения из ЕГРЮЛ лиц, участвующих в корпоративных отношени-
} 
ях. Цель исследования заключается в системном анализе проблем действующего законодательства о банкротстве в рамках упрощенной процедуры банкротства. Методы: методология данной работы основана на общем научном подходе позитивистского материализма. Применены общенаучные методы познания: анализ, синтез, гипотетико-дедуктивный метод, индукция; а также частнонаучные методы: юридико-догматический, системный, структурно-функциональный. Результаты: обосновано, что в настоящее время законодательство недостаточно регламентировано: правовые акты не учитывают всю специфику и особенности упрощенной процедуры банкротства. Существующие способы решения проблем, предусмотренные законом, не всегда действенны, особая сложность возникает, когда должник - участник корпоративных правоотношений. На основе опьта арбитражного правоприменения доказано, что у лиц, контролирующих должника, имеется возможность злоупотребления своим правом. Выводы: рассматриваемый правовой институт нуждается в перманентном совершенствовании с учетом складывающегося единообразия судебного применения норм о банкротстве. В условиях отсутствия институциональных новаций в сфере банкротства в России невозможно создать конкурентную рыночную среду и, более того, невозможно улучшить инвестиционный климат.

Ключевые слова: банкротство, упрощенная процедура, кредитор, должник, корпорация, корпоративные правоотношения.

Цитирование. Коваленко С. П. Некоторые проблемы применения арбитражным судом упрощенных процедур в деле о банкротстве // Legal Concept = Правовая парадигма. -2019 . - Т. 18, № 3. - C. 116-120. - DOI: https://doi.org/10.15688/lc.jvolsu.2019.3.17

\section{Введение}

Упрощенная процедура банкротства представляет собой ускоренное признание арбитражным судом неспособности должника в полном объеме удовлетворить требования кредиторов по денежным обязательствам, которая применяется к ограниченному кругу должников, а именно ликвидируемому должнику, отсутствующему должнику, специализированному обществу и ипотечному агенту. В производстве по делу не применяются процедуры восстановления, так как юридические лица-должники в дальнейшем исключаются из участия в гражданском обороте.

Субъектами упрощенной процедуры, применяемой в деле о банкротстве, являются отсутствующие и ликвидируемые должники (ипотечные агенты и специализированные общества не рассматриваются в рамках представленной статьи). Вместе с этим возникает определенное противоречие в процессе рассмотрения понятия упрощенной процедуры банкротства, касающееся области отнесения лиц к субъектам упрощенной процедуры.

\section{Проблемы \\ законодательного регулирования упрощенной процедуры банкротства}

Применяемая арбитражным судом упрощенная процедура банкротства отсутствующего должника является эффективным спо- собом исключения юридического лица из государственного реестра. Такую процедуру в соответствии с нормами Федерального закона от 26 октября 2002 г. № 127-Ф3 «О несостоятельности (банкротстве)» СЗ РФ 28.10.2002 № 43, ст. 4190 (далее - Закон о банкротстве) возможно применить в случаях отсутствия юридического лица в месте его нахождения, которое фактически установить невозможно в связи с прекращением предпринимательской деятельности [4]. Однако, несмотря на постоянное совершенствование норм одиннадцатой главы Закона о банкротстве, при применении упрощенных процедур в деле о банкротстве в настоящее время единства судебной практики не достигнуто.

Исключить из единого государственного реестра имеет право также регистрирующий орган при следующих условиях: 1) непредоставление отчетности в течение 12 месяцев; 2) неосуществление операций по банковским счетам; 3) наличие долгов перед бюджетом, если нет реальной возможности погасить их в рамках процедуры банкротства - п. 1 Постановления Пленума ВАС РФ от 20 декабря 2006 г. № 67 «О некоторых вопросах практики применения положений законодательства о банкротстве отсутствующих должников и прекращении недействующих юридических лиц» (далее - Пленум ВАС № 67) [2]. В этом случае штрафные санкции признаются безнадежными ко взысканию (подп. 4.3 п. 1 ст. 59 Налогового кодекса Российской Федерации). 
Каковы же последствия такого исключения, например, для корпорации? Если должник-юридическое лицо, являющийся участником корпоративных отношений, исключается из ЕГРЮЛ, то возникают проблемы с его правовым статусом в дальнейшем. При наличии кредиторов отсутствующего должника проще начать ускоренную процедуру банкротства через обращение взыскания на долю в уставном капитале. В другом случае, когда не объявляются кредиторы и на торгах долю продать затруднительно, корпорация незамедлительно должна предпринять меры для сохранения уставного капитала. В настоящее время нет правил с четкой регламентацией поведения органов управления и контроля корпорации в указанных случаях. Выход из такой ситуации видится в уменьшении уставного капитала путем выкупа доли отсутствующего должника на торгах при сохранении уставного капитала не менее минимального размера, предусмотренного законом во избежание дальнейшей ликвидации юридического лица.

Не меньший интерес представляет банкротство ликвидируемых юридических лиц, являющихся акционерами общества, имеющих контрольный или блокирующий пакет акций в уставном капитале акционерного общества. В таких случаях само акционерное общество утрачивает интерес для инвесторов и, как правило, продажа акций должником проходит по минимальной стоимости, что может привести к приобретению пакета акций должника лицом, не заинтересованным в дальнейшем развитии общества и, возможно, его ликвидации.

В итоге корпорации не только отслеживают процесс ликвидации несостоятельного должника - участника корпоративных отношений, но и в некоторых случаях берут на себя финансирование арбитражного управляющего. Затягивание процесса ликвидации, например, акционера-должника, может также привести к причинению имущественного ущерба корпорации. Пример такого случая: отсутствующий должник является участником корпоративных отношений, при этом в деятельности корпорации не участвует, не является на общее собрание и не принимает участия в голосовании по обязательным вопросам, предусмотренным законом, в результате тормозит деятельность корпорации. Еще один пример: руководитель должника, фактически прекративший свою деятельность, не проявляет интереса к исключению отсутствующего участника корпорации, не организует продажу доли в уставном капитале, в результате своим бездействием не только создает проблемы с участием в управлении корпорацией, но и может причинить ей имущественный ущерб.

Заявление о признании отсутствующего должника банкротом подается конкурсным кредитором, уполномоченным органом независимо также от размера кредиторской задолженности, но с условием наличия средств, необходимых для финансирования процедуры банкротства.

Однако серьезная проблема связана с дефицитом финансирования арбитражного управляющего и всеми затратами, относящимися к ликвидации должника: как правило, имущества ликвидируемого или отсутствующего должника недостаточно.

В исключительных случаях законом предусмотрено бюджетное финансирование банкротства, но при постоянном дефиците бюджетных средств на оплату процесса банкротства рассчитывать не приходится. В итоге финансирование осуществляют в большей мере заинтересованные лица, в том числе к ним относятся и корпорации, имеющие участника-должника.

Как следует из разъяснений, приведенных в п. 4 и 5 Постановления Пленума ВАС РФ № 67: «уполномоченный орган представляет доказательства, обосновывающие вероятность обнаружения в достаточном объеме имущества, за счет которого могут быть покрыты расходы по делу о банкротстве, а также полностью или частично может быть погашена задолженность по обязательным платежам и денежным обязательствам перед публично-правовым образованием, от имени которого выступает уполномоченный орган» [2].

При упрощенной процедуре банкротства сразу вводится процедура конкурсного производства, минуя все остальные стадии. Поскольку конкурсное производство является процедурой ликвидационной, особое внимание уделяется вопросам, связанным с максимально быстрой реализацией имущества должника по возможной цене продажи. 
С.П. Коваленко. Некоторые проблемы применения упрощенных процедур в деле о банкротстве

Следует обратить внимание на особенность, касающуюся признаков банкротства отсутствующего должника. При упрощенной процедуре признаки, предусмотренные ст. 6 Закона о банкротстве, не принимаются во внимание, один из критериев оценки - это денежное требование независимо от его размера. При этом уполномоченные органы по взысканию обязательных платежей не могут относить к признакам банкротства только денежное требование, требуется предоставить и другие доказательства, указывающие на признаки отсутствующего либо ликвидируемого должника, например: 1) имущество должника недостаточно для покрытия судебных расходов; 2) отсутствие операций по банковским счетам должника в течение последних двенадцати месяцев; 3) отсутствие признаков предпринимательской деятельности должника. И.С. Шиткина считает, что «одной из проблем, возникающих на практике при инициировании процесса несостоятельности (банкротства) в случае недостаточности имущества при добровольной ликвидации, является определение статуса должника - ликвидируемого юридического лица [1, с. 105].

Как правило, корпорации отслеживают формирование реестра требований кредиторов своего участника или акционера - отсутствующего либо ликвидируемого должника. Равно контролируют деятельность арбитражного управляющего, который обязан опубликовать сведения о признании должника банкротом, ибо реестр требований подлежит закрытию по истечении указанного срока. В связи с этим Е.А. Суханов предлагает «в ГК РФ установить принцип публичной достоверности реестра. Этот принцип предполагает, что любое добросовестное лицо, полагавшееся на данные реестра, не затрагивается несоответствием данных реестра фактическим обстоятельствам. Для акционерных обществ такая функция могла бы осуществляться профессиональными участниками рынка ценных бумаг - регистраторами, которые ведут реестр акционеров общества» [3, с. 98].

Действительно, можно согласиться с Е.А. Сухановым, так как корпорации, имеющие долги, превышающие активы организации, не заинтересованы в дальнейшем ее развитии, органы управления и контроля зачас- тую меняются, сведения в реестр о них не вносятся. В таких случаях недобросовестных участников корпоративных отношений привлечь к ответственности фактически невозможно.

\section{Выводы}

Изучение существенных для правовой оценки особенностей упрощенной процедуры банкротства, проведение анализа российского законодательства, регулирующего правоотношения в данной области, выявление особенностей субъектного состава должников, рассмотрение способов защиты прав участников банкротства позволяют прийти к выводу, что банкротство по упрощенной процедуре осуществляется с частым нарушением прав и законных интересов лиц, участвующих в нем. В настоящее время недостаточно регламентировано законодательство, а именно правовые акты не учитывают всю специфику и особенности упрощенной процедуры банкротства. Существующие способы решения проблем, предусмотренные законом, не всегда действенны, особенно не ясна роль корпорации в случае банкротства отсутствующего либо ликвидируемого должника - участника корпоративных отношений. В результате единство судебной практики по упрощенной процедуре банкротства пока не достигнуто.

Думается, что назрела необходимость детально сформировать законодательную базу, систематизировать и проанализировать судебную практику сегодняшнего дня с целью создания механизма разрешения возникающих проблем при применении упрощенной процедуры банкротства.

Как показывает анализ судебно-арбитражной практики по делам, связанным с нарушением прав кредиторов при банкротстве ликвидируемого или отсутствующего должника, у лиц, контролирующих должника, возникают большие возможности для злоупотребления. Вместе с тем грамотное использование кредиторами способов защиты нарушенных гражданских прав во многих случаях помогает добиться положительного результата.

В заключение следует отметить, что упрощенная процедура, применяемая в деле о банкротстве, нуждается в постоянной доработке с учетом анализа существующей су- 
дебной практики применения. Без институциональных новаций в сфере банкротства в России невозможно ни создание конкурентной рыночной среды, ни улучшение инвестиционного климата, что влияет в целом на экономическую политику государства.

\section{СПИСОК ЛИТЕРАТУРЫ}

1. Корпоративное право : учебный курс. В 2 т. Т. 1 / Е. Г. Афанасьева [и др.] ; отв. ред. И. С. Шиткина. - М. : Статуг, 2017. -976 c.

2. Постановление Пленума ВАС РФ от 20 декабря 2006 г. № 67 «О некоторых вопросах практики применения положений законодательства о банкротстве отсутствующих должников и прекращении недействующих юридических лиц» // Вестник ВАС РФ. - 2007. - № 2.

3. Суханов, Е. А. Сравнительное корпоративное право / Е. А. Суханов. - М. : Статут, 2014. -456 c.

4. Федеральный закон от 26 октября 2002 г. № 127-ФЗ «О несостоятельности (банкротстве)» // Собрание законодательства РФ. - 2002. - № 43. Ст. 4190 .

\section{REFERENCES}

1. Afanasyeva E.G., et al. Korporativnoe pravo: uchebnyy kurs [Corporative Law: Study Course]. Moscow, Statut Publ., 2017. 976 p.

2. Postanovlenie Plenuma VASRF ot 20.12.2006 № 67 «O nekotorykh voprosakh praktiki primeneniya polozheniy zakonodatelstva o bankrotstve otsutstvuyushchikh dolzhnikov i prekrashchenii nedeystvuyushchikh yuridicheskikh lits» [Decision of the Plenum of the Supreme Arbitration Court of the Russian Federation dated 20.12.2006 No. 67 "About Some Isues of the Practice of Applying the Provisions of the Legislation on Bankruptcy of Absent Debtors and the Termination of Inactive Legal Entities"]. Vestnik VAS RF [Bulletin of the Supreme Arbitration Court of the Russian Federation], 2007, no 2.

3. Sukhanov E.A. Sravnitelnoye korporativnoye pravo [Comparative Corporate Law]. Moscow, Statut Publ., 2014. 456 p.

4. Federalnyy zakon «O nesostoyatelnosti (bankrotstve)» ot 26 oktyabrya 2002 g. № 127-FZ [The Federal Law "On insolvency (bankruptcy)" of October 26, 202 No. 127-FZ]. Sobranie zakonodatelstva RF, 2002, no. 43, art. 4190 .

\section{Information about the Author}

Svetlana P. Kovalenko, Candidate of Sciences (Jurisprudence), Associate Professor, Department of Civil Procedure and International Law, Kuban State University, Rashpilevskaya St., 43, 350000 Krasnodar, Russian Federation, sv_kovalenko@list.ru, https://orcid.org/0000-0003-0461-6892

\section{Информация об авторе}

Светлана Павловна Коваленко, кандидат юридических наук, доцент кафедры гражданского процесса и международного права, Кубанский государственный университет, ул. Рашпилевская, 43, 350000 г. Краснодар, Российская Федерация, sv_kovalenko@list.ru, https://orcid.org/0000-0003-0461-6892 